\title{
Compound K, a metabolite of ginseng saponin, induces apoptosis via caspase-8-dependent pathway in HL-60 human leukemia cells Sung-Hee Cho ${ }^{\dagger 1}$, Kyung-Sook Chung ${ }^{\dagger 1} 3$, Jung-Hye Choi ${ }^{2}$, Dong-Hyun Kim ${ }^{1}$ and Kyung-Tae Lee*1,3
}

Address: ${ }^{1}$ Department of Pharmaceutical Biochemistry, College of Pharmacy, Kyung-Hee University, Seoul 130-701, South Korea, ${ }^{2}$ Department of Oriental Pharmaceutical Science, College of Pharmacy, Kyung-Hee University, Seoul 130-701, South Korea and ${ }^{3}$ Department of Biomedical Science, College of Medical Science, Kyung-Hee University, Seoul 130-701, South Korea

Email: Sung-Hee Cho - skstlswltjs@nate.com; Kyung-Sook Chung - adella76@hanmail.net; Jung-Hye Choi - apoptosis00@msn.com; DongHyun Kim - dhkim@khu.ac.kr; Kyung-Tae Lee* - ktlee@khu.ac.kr

* Corresponding author †Equal contributors

Published: 18 December 2009

BMC Cancer 2009, 9:449 doi:10.1 |86/|47|-2407-9-449
Received: 5 August 2009

Accepted: 18 December 2009

This article is available from: http://www.biomedcentral.com/I47I-2407/9/449

(C) 2009 Cho et al; licensee BioMed Central Ltd.

This is an Open Access article distributed under the terms of the Creative Commons Attribution License (http://creativecommons.org/licenses/by/2.0), which permits unrestricted use, distribution, and reproduction in any medium, provided the original work is properly cited.

\begin{abstract}
Background: Compound K [20-O- $\beta$-(D-glucopyranosyl)-20(S)-protopanaxadiol], a metabolite of the protopanaxadiol-type saponins of Panax ginseng C.A. Meyer, has been reported to possess antitumor properties to inhibit angiogenesis and to induce tumor apoptosis. In the present study, we investigated the effect of Compound $\mathrm{K}$ on apoptosis and explored the underlying mechanisms involved in $\mathrm{HL}-60$ human leukemia cells.
\end{abstract}

Methods: We examined the effect of Compound $K$ on the viabilities of various cancer cell lines using MTT assays. DAPI assay, Annexin V and PI double staining, Western blot assay and immunoprecipitation were used to determine the effect of Compound $\mathrm{K}$ on the induction of apoptosis.

Results: Compound $\mathrm{K}$ was found to inhibit the viability of HL-60 cells in a dose- and timedependent manner with an $\mathrm{IC}_{50}$ of $14 \mu \mathrm{M}$. Moreover, this cell death had typical features of apoptosis, that is, DNA fragmentation, DNA ladder formation, and the externalization of Annexin $\mathrm{V}$ targeted phosphatidylserine residues in HL-60 cells. In addition, compound-K induced a series of intracellular events associated with both the mitochondrial- and death receptor-dependent apoptotic pathways, namely, (I) the activation of caspases-3, -8, and -9; (2) the loss of mitochondrial membrane potential; (3) the release of cytochrome $c$ and Smac/DIABLO to the cytosol; (4) the translocation of $\mathrm{Bid}$ and $\mathrm{Bax}$ to mitochondria; and (5) the downregulations of $\mathrm{Bcl}-2$ and $\mathrm{Bcl}-\mathrm{xL}$. Furthermore, a caspase- 8 inhibitor completely abolished caspase- 3 activation, Bid cleavage, and subsequent DNA fragmentation by Compound K. Interestingly, the activation of caspase- 3 and -8 and DNA fragmentation were significantly prevented in the presence of cycloheximide, suggesting that Compound $\mathrm{K}$-induced apoptosis is dependent on de novo protein synthesis.

Conclusions: The results indicate that caspase- 8 plays a key role in Compound K-stimulated apoptosis via the activation of caspase-3 directly or indirectly through Bid cleavage, cytochrome $c$ release, and caspase- 9 activation. 


\section{Background}

Ginseng, the root and rhizomes of different Panax species (Araliaceae), is one of the most commonly used as traditional medicines in East Asia. Furthermore, the saponins of ginseng (ginsenosides) are its major active components and have been shown to possess anti-inflammatory, antitumor, and neuroprotective activities [1]. The pharmacological actions of these ginsenosides have been attributed to their biotransformations by intestinal bacteria [2]. Protopanaxadiol ginsenoside is metabolized primarily to 20$O-\beta$-(D-glucopyranosyl)-20(S)-protopanaxadiol (Compound K, Figure 1A) by intestinal bacteria via the stepwise cleavage of sugar moieties [3]. Furthermore, Compound K has been shown to inhibit glucose uptake and to reverse multi-drug resistance in tumor cells, but to be non-toxic to normal cells [4]. Compound $\mathrm{K}$ has also been reported to reverse benzo [a]pyrene-induced mutagenicity nd clastogenic activity [5], to inhibit tumor metastasis by suppressing invasion [6], and to stimulate apoptosis in several tumor cell lines $[7,8]$.

Apoptosis is a selective process of physiological cell deletion that plays an important role in the balance between cellular replication and death. Furthermore, it has been suggested that some cancer chemotherapeutics and chemopreventives exert their effects by triggering either apoptotic cell death or cell cycle transition, and accordingly, the induction of tumor cell apoptosis is used to predict tumor treatment response $[9,10]$. Apoptotic signaling can proceed via two pathways, i.e., via death receptors expressed on the plasma membranes of cells or alternatively via mitochondria, which contain several proteins that regulate apoptosis. The death receptor pathway is initiated by the ligation of membrane bound tumor necrosis factor (TNF) or Fas receptors, which result in a caspase-8dependent cascade and subsequent cell death [11]. During this cascade, caspase- 8 cleaves Bid and induces cytochrome $c$ release and/or directly activates caspase-3 [12]. On the other hand, the mitochondrial pathway involves cytochrome $c$ release, which leads to caspase- 9 activation and a proteolytic caspase cascade [13]. Thus, caspase cascades appear to be a central component in the apoptotic process. However, accumulating evidence indicates that apoptosis is also induced by caspase-independent pathways [14], which has been suggested to involve mitochondrial release of apoptosis-inducing factor (AIF) and/or endonuclease G $[15,16]$.

Human leukemia results from multiple mutations that lead to abnormalities in the expressions and functions of genes that maintain the delicate balance between proliferation, differentiation, and apoptosis. Continued research on the molecular aspects of leukemia cells has resulted in the developments of several potentially useful therapeutic agents. In this context, we investigated that Compound $\mathrm{K}$ induced apoptosis and the mechanism involved the activation of caspase- 8 system.

\section{Methods \\ Cells and reagents}

HL-60 human promyelocytic leukemia, U-937 human histocytic lymphoma, HeLa human negroid cervix epitheloid carcinoma, A549 human lung adenocarcinoma, HepG2 human hepatoblastoma, P388 mouse lymphoblast, and A431 human epidermoid carcinoma cells were obtained from the Korean cell line bank (KCLB, Seoul, Korea) and were cultured according to the KCLB recommendations.

Compound $\mathrm{K}$ used in this study was isolated from Panax ginseng and structural identities were determined spectroscopically $\left({ }^{1} \mathrm{H}\right.$ and $\left.{ }^{13} \mathrm{NMR}, \mathrm{IR}, \mathrm{MS}\right)$ as described previously [17]. The identity of isolated compound was confirmed by LC-MS and was found to be $>98 \%$ pure. RPMI 1640 medium, fetal bovine serum (FBS), penicillin, and streptomycin were obtained from Life Technologies Inc. (Grand Island, NY). 3-(4,5-Dimethylthiazol-2-yl)2,5-diphenyl-tertazolium bromide (MTT), dimethyl sulfoxide (DMSO), RNase A, leupeptin, aprotinin, phenylmethylsulfonylfluoride (PMSF), 4',6-diamidino-2phenylindole-dihydrochloride (DAPI), Triton X-100, Nonidet P-40, protein A/G-Sepharose beads, and propidium iodide (PI) were purchased from Sigma Chemical Co. (St. Louis, MO). The following antibodies for caspase-3, poly(ADP-ribose) polymerase (PARP), Bid, tBid, Bax, Bcl2 , Bcl-xL, anti-Smac/DIABLO, Fas, FasL, $\alpha$-tubulin and $\beta$ actin were purchased from Santa Cruz Biotechnology (Santa Cruz, CA). The antibodies for Fas-associated death domain protein (FADD), X-linked inhibitor of apoptosis protein (XIAP), caspase-8, caspsae-9, and cytochrome $c$ were purchased from BD Biosciences, Pharmingen (San Diego, CA). The antibody for COX IV was purchased from Cell Signaling Technology (Beverly, MA), and Bax 6A7 antibody was obtained from Trevigen, Inc. (Gaithersburg, MD). z-VAD-fmk and z-DEVD-fmk, z-IETD-fmk, and zLEHD-fmk were purchased from Calbiochem (Bad Soden, Germany).

\section{MTT assay}

The cytotoxicity was assessed using a MTT assay [18]. Briefly, the cells $\left(5 \times 10^{4}\right)$ were seeded in each well containing $100 \mu \mathrm{L}$ of the RPMI medium supplemented with $3 \%$ FBS in a 96-well plate. After $24 \mathrm{~h}$, various concentrations of Compound $\mathrm{K}$ were added. After $48 \mathrm{~h}, 50 \mu \mathrm{L}$ of MTT ( $5 \mathrm{mg} / \mathrm{mL}$ stock solution) was added and the plates were incubated for an additional $4 \mathrm{~h}$. The medium was discarded and the formazan blue, which was formed in the cells, was dissolved with $100 \mu$ LDMSO. The optical density was measured at $540 \mathrm{~nm}$. 
A

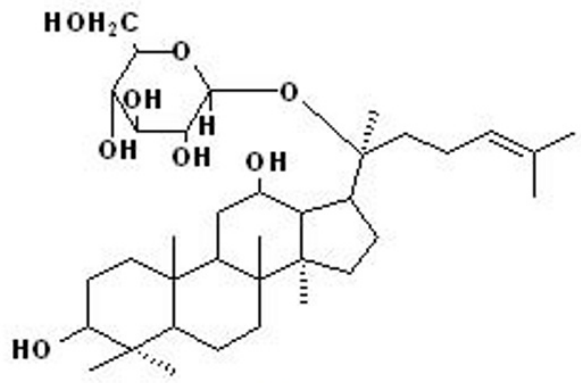

B

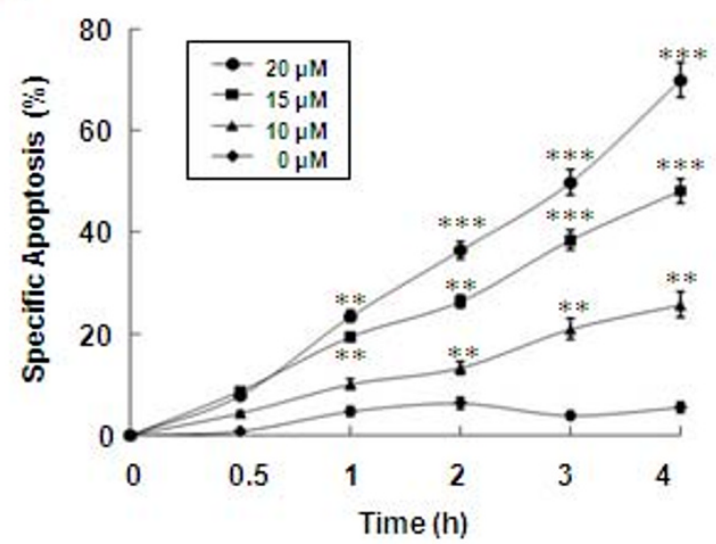

C

Compound $\mathrm{K}(20 \mu \mathrm{M})$

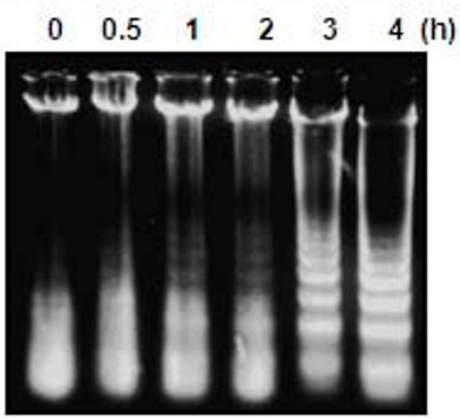

D

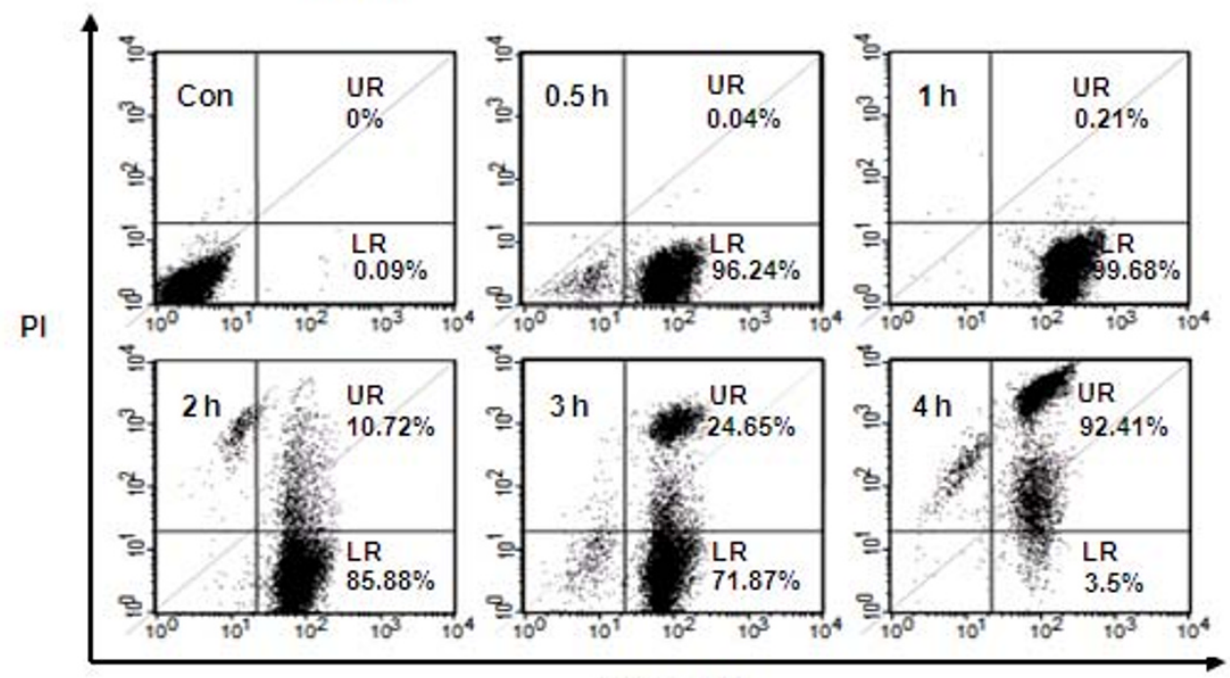

Annexin V

Figure I

Compound $\mathrm{K}$ induced apoptosis in HL-60 cells. (A) The chemical structure of Compound K. (B) Cells were treated with various concentrations $(10,15,20 \mu \mathrm{M})$ of Compound $\mathrm{K}$ for the indicated times. Extents (\%) of DNA fragmentation were determined by fluorometric method using DAPI, as described in Methods. Data are presented as means \pm SD of three independent experiments. $* P<0.05$, $* * P<0.01$ and $* * * P<0.001$ vs. the control group; the significances of differences between treatments were determined using the Student's t-test. (C) Cells were treated with or without $20 \mu \mathrm{M}$ Compound K for the indicated times. Fragmentation of genomic DNA was extracted and resolved on $2 \%$ agarose gels. Apoptotic DNA fragmentation was visualized by ethidium bromide staining. (D) Cells treated with or without $20 \mu \mathrm{M}$ of Compound $\mathrm{K}$ for the indicated times were co-stained with PI and FITC-conjugated Annexin V, which specifically detected the translocation of phosphatidylserine (PS). Cells were then examined by flow cytometry (LR; low right, UR; upper right). 


\section{Detection and quantification of DNA fragmentation}

DNA fragmentation was quantified using DAPI staining and analysis of DNA fragmentation by agarose gel electrophoresis was performed as described previously [19]. In brief, cells were lysed in a solution of $5 \mathrm{mM}$ Tris- $\mathrm{HCl}(\mathrm{pH}$ 7.4) and $1 \mathrm{mM}$ EDTA containing $0.5 \%$ (w/v) Triton X-100 for $20 \mathrm{~min}$ on ice. After centrifugation at 25,000 $\mathrm{g}$ for 20 min, the lysate and supernatant were sonicated for $15 \mathrm{sec}$ and the level of DNA in each fraction was measured by a fluorometric method using DAPI. The amount of the fragmented DNA was calculated as the ratio of the amount of DNA in the supernatant to that in the lysate. Genomic DNA was prepared and was performed in a $1.5 \%(\mathrm{w} / \mathrm{v})$ agarose gel in $40 \mathrm{mM}$ Tris-acetate buffer $(\mathrm{pH} 7.4)$ at $50 \mathrm{~V}$ for $1 \mathrm{~h}$. The fragmented DNA was visualized by staining with ethidium bromide after electrophoresis.

\section{$P I$ and Annexin $V$ double staining}

For PI and Annexin V double staining, cells were suspended with $100 \mu \mathrm{l}$ of binding buffer (10 mM HEPES/ $\mathrm{NaOH}, 140 \mathrm{mM} \mathrm{NaCl}, 2.5 \mathrm{mM} \mathrm{CaCl}_{2}, \mathrm{pH} \mathrm{7.4)}$ and stained with $5 \mu \mathrm{L}$ of FITC-conjugated Annexin $\mathrm{V}$ and 10 $\mu \mathrm{L}$ of PI $(50 \mu \mathrm{g} / \mathrm{mL})$ for $15 \mathrm{~min}$ at room temperature in dark place and then added $400 \mu$ l binding buffer, and analyzed by the fluorescence-activated cell sorting (FACS) cater-plus flow cytometry (Becton Dickinson Co, Heidelberg, Germany)

\section{Analysis of mitochondrial membrane potential (MMP, $\left.\Delta \Psi_{\mathrm{m}}\right)$}

Changes in mitochondrial transmembrane potential were monitored by flow cytometric analysis. Cells were incubated with $50 \mathrm{nM}$ 3,3'-dihexyloxacarbocyanine iodide $\left(\mathrm{DiOC}_{6}\right)$ for $30 \mathrm{~min}$, washed twice with PBS, and analyzed by flow cytometric analysis (Becton Dickinson Co, Heidelberg, Germany) with excitation and emission settings of 484 and $500 \mathrm{~nm}$, respectively. To ensure that $\mathrm{DiOC}_{6}$ uptake was specific for $\Delta \Psi_{m}$, we also treated cells with 50 $\mu \mathrm{M}$ carbonyl cyanide $m$-chlorophenylhydrazone (CCCP) or $5 \mu \mathrm{M}$ cyclosporine A (CsA). CCCP was used as a reference depolarizing agent and CsA was used as an inhibitor of mitochondrial permeability transition.

\section{Protein extraction and Western blot analysis}

Cells were collected by centrifugation at $200 \mathrm{~g}$ for $10 \mathrm{~min}$ at $4{ }^{\circ} \mathrm{C}$. The cells were then washed twice with ice-cold PBS, and centrifuged at $200 \mathrm{~g}$ for $5 \mathrm{~min}$. The cell pellet obtained was then resuspended in $1 \times$ protein lysis buffer (Intron, Seoul, Korea). Equal amounts of cell lysates were separated by SDS- polyacrylamide gel and transferred to nitrocellulose membranes for Western blot analysis using the indicated primary antibodies. HRP-conjugated secondary antibodies were detected using an ECL (Amersham, Buckingham-shire, England) detection system.

\section{Preparation of mitochondrial proteins}

Cells were collected by centrifugation at $200 \mathrm{~g}$ for $10 \mathrm{~min}$ at $4{ }^{\circ} \mathrm{C}$. The cells were then washed twice with ice-cold PBS, and centrifuged at $200 \mathrm{~g}$ for $5 \mathrm{~min}$. The cell pellet obtained was then resuspended in ice-cold cell extraction buffer (20 mM HEPES-KOH, pH 7.5, $10 \mathrm{mM} \mathrm{KCl,} 1.5 \mathrm{mM}$ $\mathrm{MgCl}_{2}, 1 \mathrm{mM}$ EDTA, $1 \mathrm{mM}$ EGTA, $1 \mathrm{mM}$ dithiothreitol, $100 \mu \mathrm{M}$ PMSF, and protease inhibitor cocktail) for $30 \mathrm{~min}$ on ice. The cells were then homogenized with a glass dounce and a B-type pestle (80 strokes), homogenates were spun at $15,000 \mathrm{~g}$ for $15 \mathrm{~min}$ at $4^{\circ} \mathrm{C}$, and the supernatant (cytosolic fraction) was removed whilst taking care to avoid the pellet. The resulting pellet (mitochondrial fraction) was resuspended in extraction buffer. Cell lysates were fractionated in SDS- polyacrylamide gels and transferred to nitrocellulose membranes fot immunoblot analysis using the indicated primary antibodies. Immunopositive bands were visualized by ECL kit (Amersham, Buckingham-shire, England).

\section{Immunoprecipitation}

After harvesting and washing, pellets were lysed in EBC buffer (30 mM Tris-HCl, pH 7.5, $150 \mathrm{mM} \mathrm{NaCl}, 10 \%$ glycerol, $1 \mathrm{mM}$ EDTA, $2.5 \mathrm{mM}$ EGTA, $5 \mathrm{mM} \mathrm{NaF}, 0.1 \mathrm{mM}$ $\mathrm{Na}_{3} \mathrm{VO}_{4}, 1 \%$ Triton X-100 and protease inhibitor) for 15 min on ice. After centrifugation $(10,000 \mathrm{~g}, 5 \mathrm{~min})$, protein concentrations were determined. Equal amount of protein $(100 \mu \mathrm{g})$ was incubated with anti-Smac/DIABLO, anti-tBid, anti-Bax, and anti-Fas antibodies for $12 \mathrm{~h}$ at $4^{\circ} \mathrm{C}$, followed by incubation with $40 \mu \mathrm{L}$ protein A-Sepharose beads for $4 \mathrm{~h}$. The protein complex was washed 4 times with EBC buffer and released from the beads by boiling in $6 \times$ sample buffer $(350 \mathrm{mM}$ Tris, $\mathrm{pH} 6.8,10 \%$ SDS, $30 \% \quad \beta$-mercaptoethanol, $6 \%$ glycerol, $0.12 \%$ bromophenolblue) for $5 \mathrm{~min}$. The reaction mixture was then resolved by a 10 - 12\% SDS- polyacrylamide gels, transferred to nitrocellulose membrane and probed with anti-XIAP, anti-Bax 6A7 (Trevigen Inc., Gaithersburg, $\mathrm{MD}$ ), anti-Bcl-xL, anti-Bcl-2, anti-tBid, anti-Bax, anti-caspase-8, anti-Fas, anti-FasL, and anti-FADD antibodies. Immuno-positive bands were visualized by ECL kit (Amersham, Buckingham-shire, England).

\section{Statistical analysis}

Data presented are the means \pm S.D. of results from three independent experiments with similar patterns. ${ }^{*} P<0.05$, ${ }^{* *} P<0.01,{ }^{* * *} P<0.001$ vs control group, ${ }^{\dagger} P<0.05$, ${ }^{\dagger \dagger}$ $P<0.01,{ }^{\dagger \dagger} P<0.001$ vs Compound K-treated group; significance of difference between treated groups by Student's $t$-test. 


\section{Results \\ Compound $K$ inhibited HL-60 cell growth and induced apoptosis}

We examined the effect of Compound $\mathrm{K}$ on the viabilities of various cancer cell lines using MTT assays, and assessed its effects using $\mathrm{IC}_{50}$ values (Table 1 ). $\mathrm{IC}_{50}$ values were found to fall in the range $14.1-59.4 \mu \mathrm{M}$, and Compound $\mathrm{K}$ was found to have marked cytotoxic effects on human leukemia cell lines, including HL-60 and U937. Further experiments were performed using HL-60 cells to evaluate the effect of Compound $\mathrm{K}$ on apoptosis and to identify the mechanism involved. To determine whether the cell growth inhibitory effect of Compound $\mathrm{K}$ is associated with the induction of apoptosis, DNA fragmentation was evaluated using DAPI assay and by agarose gel electrophoresis. DAPI assay revealed that Compound $\mathrm{K}$ caused DNA fragmentation, in a time- and dose-dependent manner in HL-60 cells (Figure 1B). Furthermore, a typical ladder pattern of internucleosomal DNA fragmentation was observed after treating HL-60 cells with Compound K (20 $\mu \mathrm{M}$ ) for $4 \mathrm{~h}$ (Figure $1 \mathrm{C}$ ). To further characterize Compound K-induced apoptosis, we assessed the translocation of phosphatidylserine (PS) using Annexin V and PI double staining. As shown in Figure 1D, cell numbers in lower-right quadrants, which correspond to early apoptotic cells (Annexin V-positive), were increased up to $99 \%$ after treating cells with Compound $\mathrm{K}(20 \mu \mathrm{M}$, for $1 \mathrm{~h})$, and about $92 \%$ of cells were in the late apoptotic stage after $4 \mathrm{~h}$.

\section{Caspase involvement in Compound K-induced apoptosis} To identify the mechanism involved in Compound Kinduced apoptosis, we investigated the activation of caspase- $8,-9,-3$, and the cleavage of PARP. As shown in Figure 2A, Compound $\mathrm{K}$ significantly increased the activation of caspase- $8,-9,-3$ and the cleavage of PARP (an endogenous substrate of caspase-3) in a time-dependent manner. Following treatment with Compound $\mathrm{K}$, the cleaved form s of caspase- 8 and -3 were observed at $0.5 \mathrm{~h}$ and $1 \mathrm{~h}$, respectively, whereas caspase- 9 and PARP were

Table I: Cell viabilities of Compound $\mathrm{K}$ in various cancer cell lines in vitro

\begin{tabular}{cc}
\hline Cell lines & $I_{\mathbf{5 0}}(\mu \mathrm{M})^{\mathbf{a}}$ \\
\hline HL-60 & 14.1 \\
U937 & 16.5 \\
HeLa & 29.9 \\
A549 & 37.9 \\
HepG2 & 59.4 \\
P388 & 18.4 \\
A43 I & 37.9
\end{tabular}

a $\mathrm{C}_{50}$ is defined as the concentration that results in a $50 \%$ decrease in the number of cells compared to that of the control cultures in the absence of Compound $\mathrm{K}$. The values represent the means of results from three independent experiments with similar patterns. cleaved after $3 \mathrm{~h}$ of treatment in HL-60 cells. Additionally Figure 2B showed that $z$-VAD-fmk (a broad caspase inhibitor), z-DEVD-fmk (a specific caspase-3 inhibitor), and zIETD-fmk (a specific caspase- 8 inhibitor) all markedly attenuated Compound K-stimulated DNA fragmentation, thus indicating that Compound K-induced apoptosis is largely dependent on the activation of caspases- 8 and -3 . In contrast, $z$-LEHD-fmk (a specific caspase- 9 inhibitor) only partially inhibited DNA fragmentation.

\section{Compound $K$ induced apoptosis involving the loss of $\Delta \Psi_{\mathrm{m}}$ and the release of cytochrome $c$ and Smac/DIABLO}

Because Compound $\mathrm{K}$ induced caspase-9 cleavage in HL60 cells, the initial caspase in the mitochondrial apoptotic pathway, we investigated whether Compound $\mathrm{K}$ was capable of inducing $\Delta \Psi_{m}$ depolarization using $\mathrm{DiOC}_{6}$, a mitochondria-specific voltage-dependent dye. Treatment of cells with Compound $\mathrm{K}(20 \mu \mathrm{M})$ caused the dissipation of $\Delta \Psi_{m}$ as did CCCP (the positive control) (Figure 3A). In order to determine whether this loss of $\Delta \Psi_{m}$ was associated with Compound K-induced apoptosis, we utilized CsA ( $5 \mu \mathrm{M}$; an inhibitor of mitochondrial permeability transition). Pretreatment with CsA significantly inhibited the Compound K-induced loss of $\Delta \Psi_{m}$ and caspase-3 activation, but had no effect on caspase- 8 activation (Figure 3B). Additionally, DAPI staining and agarose gel electrophoresis assays showed that CsA partially inhibited Compound K-induced DNA fragmentation (Figure 3C and 3D), indicating that $\Delta \Psi_{m}$ is partially involved in Compound K-induced apoptosis. Furthermore the levels of cytosolic cytochrome $c$ and Smac/DIABLO were elevated by Compound $\mathrm{K}$ in HL-60 cells, whereas X-linked IAP (XIAP) levels decreased, which suggests the involvement of the mitochondrial pathway (Figure 3E). To determine whether Smac/DIABLO release by Compound $\mathrm{K}$ is able to dissociate XIAP from caspases, we immunoprecipitated Smac/DIABLO, and detected bound XIAP by Western blotting. We found that Compound $\mathrm{K}$ significantly increased the interaction between Smac/DIABLO and XIAP (Figure 3F). The above results suggest that Compound $\mathrm{K}$ stimulates the release of Smac/DIABLO from mitochondria and the association between Smac/DIABLO and XIAP, and that this inhibits the XIAP - caspase interaction and consequently stimulates apoptosis.

\section{Compound $K$ induced the translocations of $t B i d$ and $B a x$ and downregulated $\mathrm{BCl}-2$ and $\mathrm{BCl}-\mathrm{xL}$}

To investigate the mechanism underlying Compound $\mathrm{K}$ induced $\Delta \Psi_{m}$ changes in HL-60 cells, we examined the translocations of cytosolic Bid and Bax into mitochondria after treating cells with Compound K. As shown in Figure $4 \mathrm{~A}$, treatment with Compound $\mathrm{K}$ reduced the cytosolic levels of pro-apoptotic Bid and Bax, but increased their mitochondrial levels. In addition, the mitochondrial expressions of Bcl-2 and Bcl-xL (mitochondrial anti-apop- 


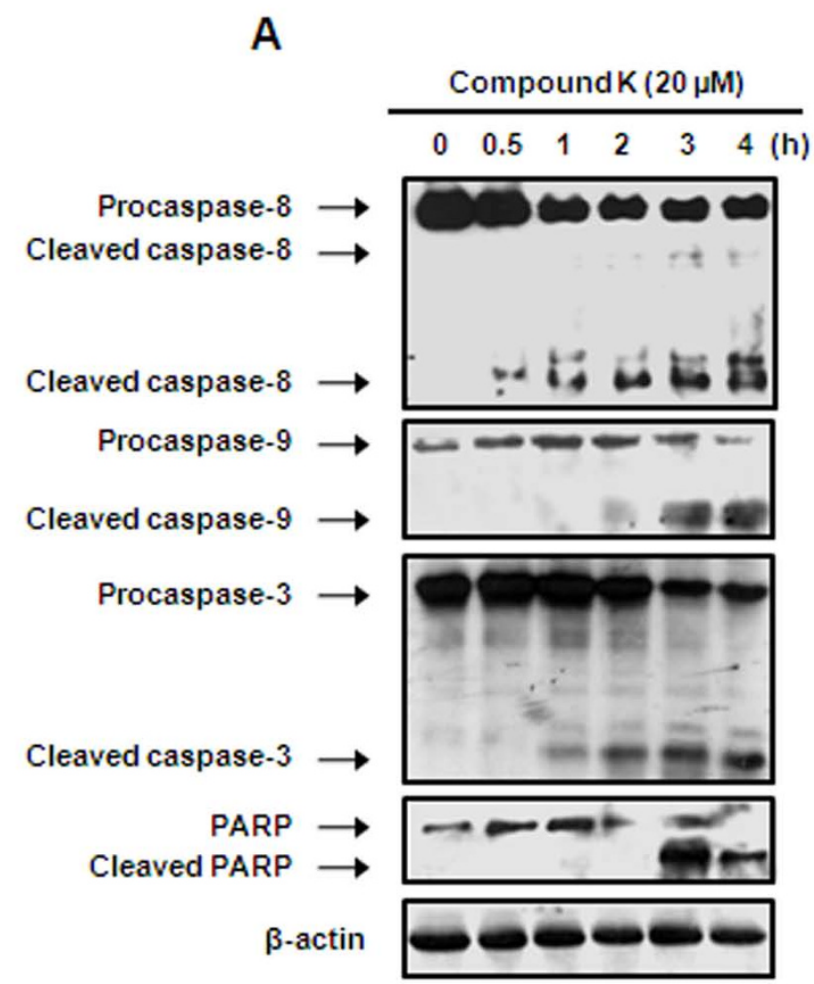

B

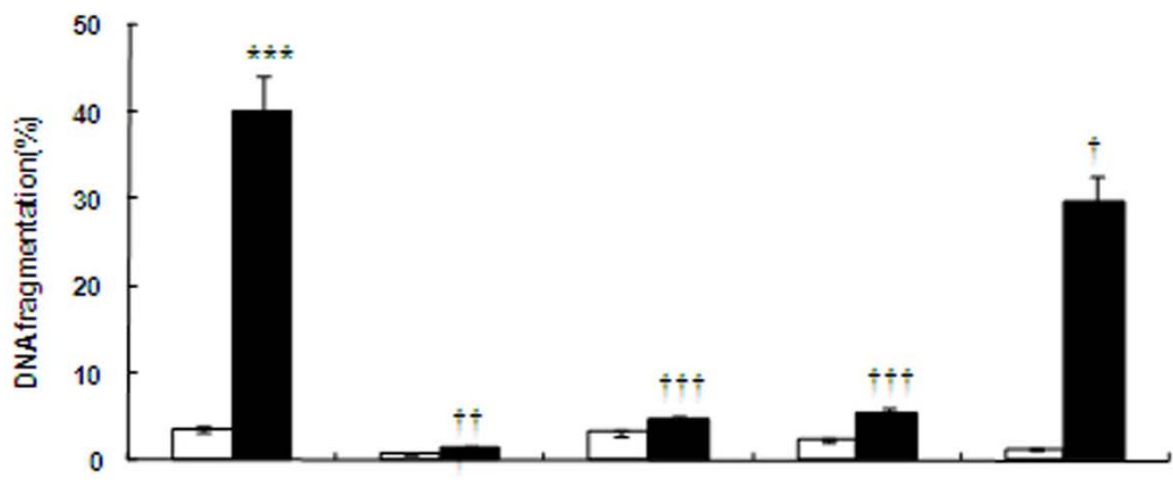

\begin{tabular}{|c|c|c|c|c|c|}
\hline CompoundK $(20 \mu \mathrm{M})$ & -+ & -+ & -+ & -+ & -+ \\
\hline Z-VAD-fmk $(50 \mu M)$ & $-\quad-$ & ++ & $-\quad-$ & $-\quad-$ & $-\quad-$ \\
\hline 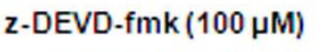 & - & - & + & - & - \\
\hline$z$-IETD-fmk (100 $\mu \mathrm{M})$ & - & - & - & + & - \\
\hline Z-LEHD-fmk (100 $\mu \mathrm{M})$ & $-\quad-$ & - & - & - & + \\
\hline
\end{tabular}

Figure 2

Compound $K$ induced the apoptosis of HL-60 cells via caspase activation. (A) Cells were treated with $20 \mu M$ of Compound $\mathrm{K}$ for the indicated times. Caspase-8, caspase-9, caspase-3, and PARP were analyzed by Western blotting. $\beta$-actin was used as an internal control. Experiments were repeated three times and similar results were obtained. (B) Effects of the caspase inhibitors (z-VAD-fmk, z-DEVD-fmk, z-IETD-fmk and z-LEHD-fmk) on apoptosis were determined by testing for Compound K-induced DNA fragmentation. HL-60 cells were pretreated with/without $50 \mu M$ z-VAD-fmk, $100 \mu M$ z-DEVD-fmk, $100 \mu \mathrm{M}$ z-IETD-fmk or $100 \mu \mathrm{M}$ z-LEHD-fmk for I h, and then treated with Compound K (20 $\mu \mathrm{M}$ for $2 \mathrm{~h})$. DNA fragmentation was measured by DAPI staining. White square: None, Black square: Compound K. The data presented are the means \pm SD of results obtained from three independent experiments. $* * * P<0.00 \mathrm{I}$ vs. control group, $t+P<0.0 \mathrm{I}, \mathrm{t}+\mathrm{P}<0.00 \mathrm{I}$ vs. the Compound K-treated group; significances were determined using the Student's $t$-test. 
A

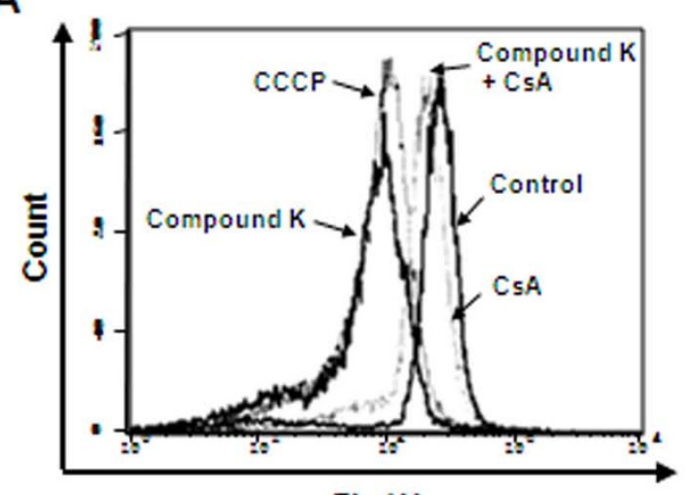

FL-1H

C

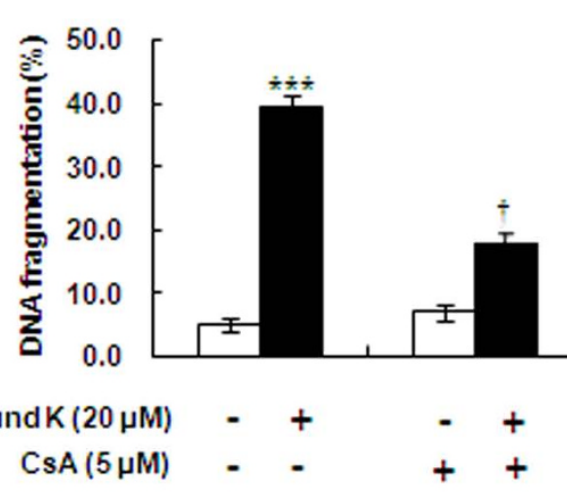

E

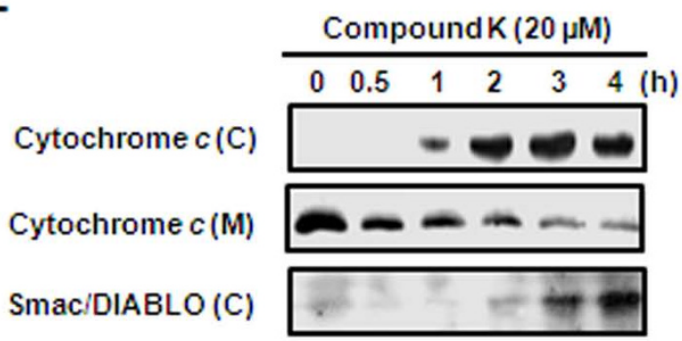

$\mathrm{XIAP} \leadsto \infty \cdots \cdots$

a-tubulin(C) $-\infty-\infty$

$\operatorname{coxIV}(\mathrm{M})=-\infty-\infty$

$\beta$-actin $\rightarrow \infty$
B

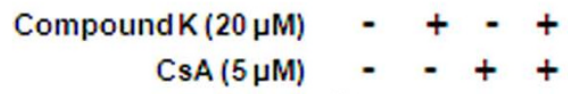

$$
\begin{aligned}
& \begin{aligned}
\text { Procaspase-8 } & \rightarrow \square= \\
\text { Cleaved caspase-8 } \rightarrow & ==
\end{aligned} \\
& \text { Procaspase-3 } \rightarrow \infty-\infty \\
& \beta \text {-actin } \infty \infty \infty
\end{aligned}
$$

D

$$
\begin{array}{r}
\text { CompoundK }(20 \mu \mathrm{M}) \quad-\quad+-+ \\
\operatorname{CsA}(5 \mu \mathrm{M}) \quad-\quad+++
\end{array}
$$

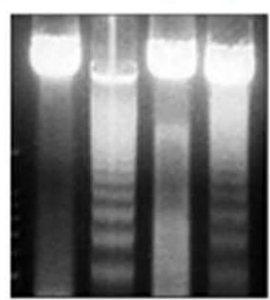

$\mathbf{F}$

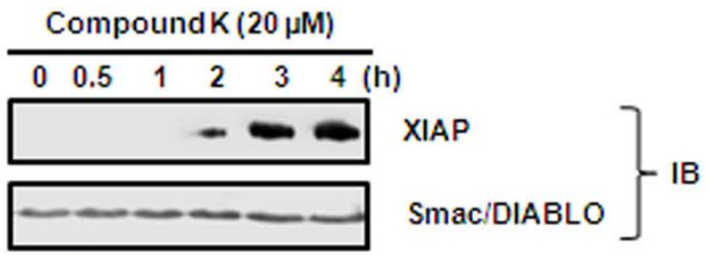

IP: Smac/DIABLO

Figure 3 (see legend on next page) 
Figure 3 (see previous page)

Compound $\mathrm{K}$ caused a loss in mitochondrial membrane potential and induced the translocations of cytochrome $c$ and Smac/DIABLO from mitochondria to the cytoplasm in HL-60 cells. (A) Cells were pretreated with 5 $\mu \mathrm{M}$ cyclosporin $\mathrm{A}$ (CsA) for 30 min and then treated with $20 \mu \mathrm{M}$ of Compound $\mathrm{K}$ for $2 \mathrm{~h}$, stained with DiOC 6 , and analyzed by flow cytometry. CCCP (I00 $\mu \mathrm{M})$ was used as a positive control. (B) Cells were pretreated as described in the legend of Figure 3 (A). Cleavages of procaspase- 8 and -3 were analyzed by Western blotting. DNA fragmentation was measured using (C) DAPI assays and (D) fragmented genomic DNA was extracted and resolved on $2 \%$ agarose gel. Data presented are the means \pm SD of three independent experiments. $* * * P<0.00 \mathrm{I}$ vs. untreated controls, $t P<0.05$ vs. Compound K-treated cells; significances were determined using the Student's t-test. (E) Cells were harvested after being incubated with Compound $\mathrm{K}$ at $20 \mu \mathrm{M}$ for the indicated times. Mitochondrial (M) and cytosolic (C) fractions were prepared as described in Methods. Cytochrome $c$, Smacl DIABLO, and XIAP were analyzed by Western blotting. $\alpha$-tubulin, cytochrome $c$ oxidase (COX) IV, and $\beta$-actin were used as internal controls. (F) Compound $\mathrm{K}$ induced an interaction between XIAP and Smac/DIABLO. Cells were treated with $20 \mu \mathrm{M}$ of Compound $\mathrm{K}$ for the indicated times. Smac/DIABLO was immunoprecipitated from total protein lysates and proteins were subjected to Western blotting for anti-XIAP antibody (IP: immunoprecipitation, IB; immunoblotting).

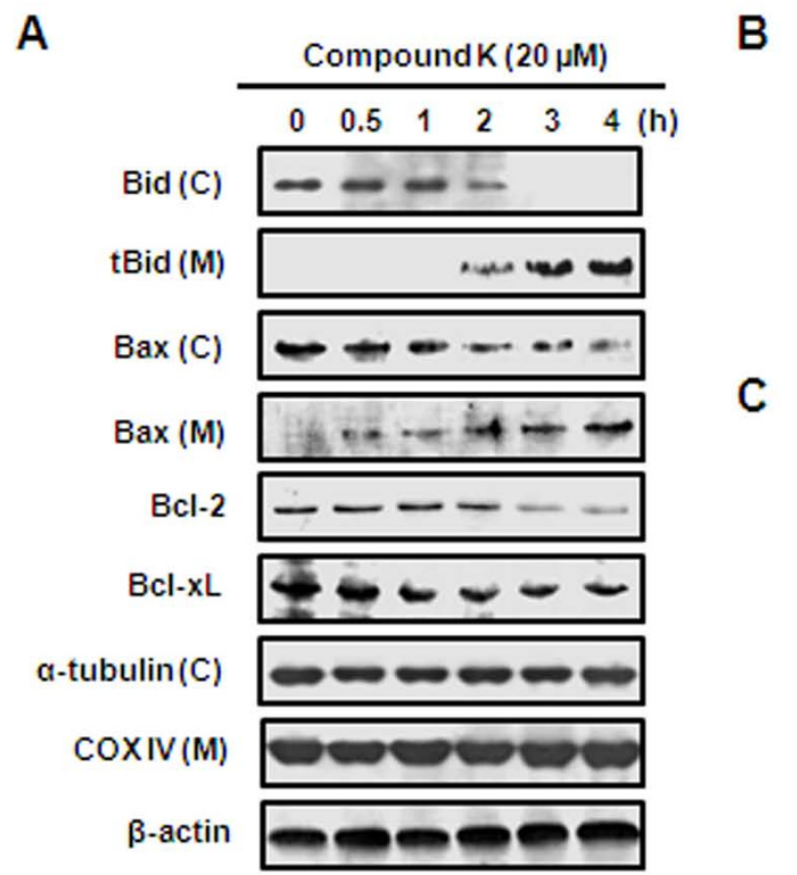

B

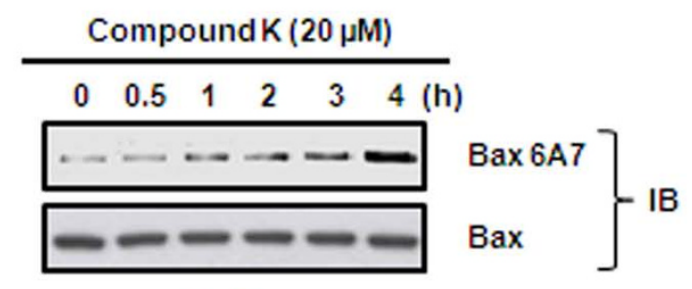

IP: Bax
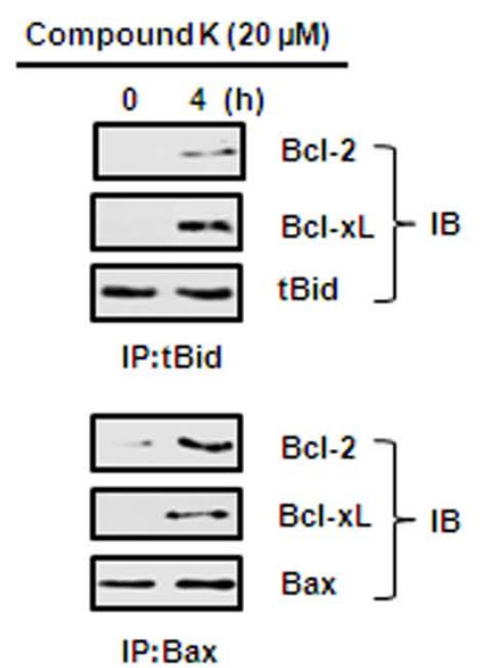

$\left.\begin{array}{l}B c l-2 \\ B c l-x L \\ B a x\end{array}\right\} \mathrm{IB}$

IP:Bax

\section{Figure 4}

Effect of Compound $\mathrm{K}$ on the expressions of $\mathrm{BCl}-2$ family proteins for Compound $\mathrm{K}$-induced apoptosis in $\mathrm{HL}-60$ cells. (A) Cells were harvested after being incubated with Compound $K(20 \mu \mathrm{M})$ for the indicated times. Mitochondrial (M) and cytosolic (C) fractions were prepared as described in Methods. Bid, tBid, Bax, Bcl-2, and Bcl-xL were analyzed by Western blotting. $\alpha$-tubulin, COX IV and $\beta$-actin were used as internal controls. (B) HL-60 cells were treated with $20 \mu \mathrm{M}$ of Compound $\mathrm{K}$ for $4 \mathrm{~h}$ and cell lysates were prepared. Bax was immunoprecipitated from total protein lysates and proteins were subjected to Western blotting for anti-Bax 6A7 using specific antibody. (C) Compound K-induced interactions between Bcl-2 family members. tBid and Bax were immunoprecipitated using specific antibodies from total protein lysates and Western blotting was conducted for $\mathrm{Bcl}-2$ and $\mathrm{Bcl}-\mathrm{xL}$ (IP; immunoprecipitation, IB; immunoblotting). 
totic proteins) were reduced by Compound K. It has been shown that apoptotic stimuli trigger a conformational change in Bax and induce its translocation to mitochondria [20]. As shown in Figure 4B, immunoprecipitation assays were performed using an anti-Bax 6A7 antibody recognizing only conformationally changed Bax, and Compound $\mathrm{K}$ induced a time-dependent increase in conformationally changed Bax. Furthermore, treatment with Compound $\mathrm{K}$ for $4 \mathrm{~h}$, significantly enhanced bindings of tBid to $\mathrm{Bcl}-2$ or $\mathrm{Bcl}-\mathrm{xL}$, and increased association between Bax and Bcl-2 or Bcl-xL (Figure 4C). These results suggest the Compound K-induced translocations of tBid and Bax stimulates their direct binding to Bcl-2 or Bcl-xL in mitochondria, and that this perturbs the balance between antiand pro-apoptotic Bcl-2 family proteins in mitochondria.

\section{Compound $K$ induced apoptosis via the caspase-8- dependent pathway}

Because Compound $\mathrm{K}$ induced caspase- 8 activation and Bid cleavage (Figure $2 \mathrm{~A}$ and $4 \mathrm{~A}$ ), we further examined the mechanism of caspase- 8 activation during Compound K- induced apoptosis using z-IETD-fmk. As shown in Figure 5A, treatment with $z$-IETD-fmk inhibited caspase- 3 activation, Bid translocation, and Bcl-2 downregulation by Compound K. Furthermore, Compound K-induced internucleosomal DNA fragmentation was markedly abolished in the presence of z-IETD-fmk (Figure 5B). To determine whether DISC (death-inducing signaling complex) formation is involved in the Compound K-induced activation of caspase- 8 and apoptosis, Fas was immunoprecipitated and bindings of FasL, FADD, and procaspase8 to Fas were evaluated by Western blotting (Figure $5 \mathrm{C}$ ). The association of Fas with FasL and FADD was observed from $0.5 \mathrm{~h}$ after Compound $\mathrm{K}$ treatment, while the binding of procaspase- 8 to Fas was observed at $1 \mathrm{~h}$. These findings suggest that Compound K stimulates DISC formation and the subsequent activation of procaspase- 8 .

\section{Cycloheximide prevented Compound K-induced caspase-8 and $\mathbf{- 3}$ activation and DNA fragmentation}

To test the possibility that new protein synthesis is required for Compound K-induced apoptosis, HL-60 cells

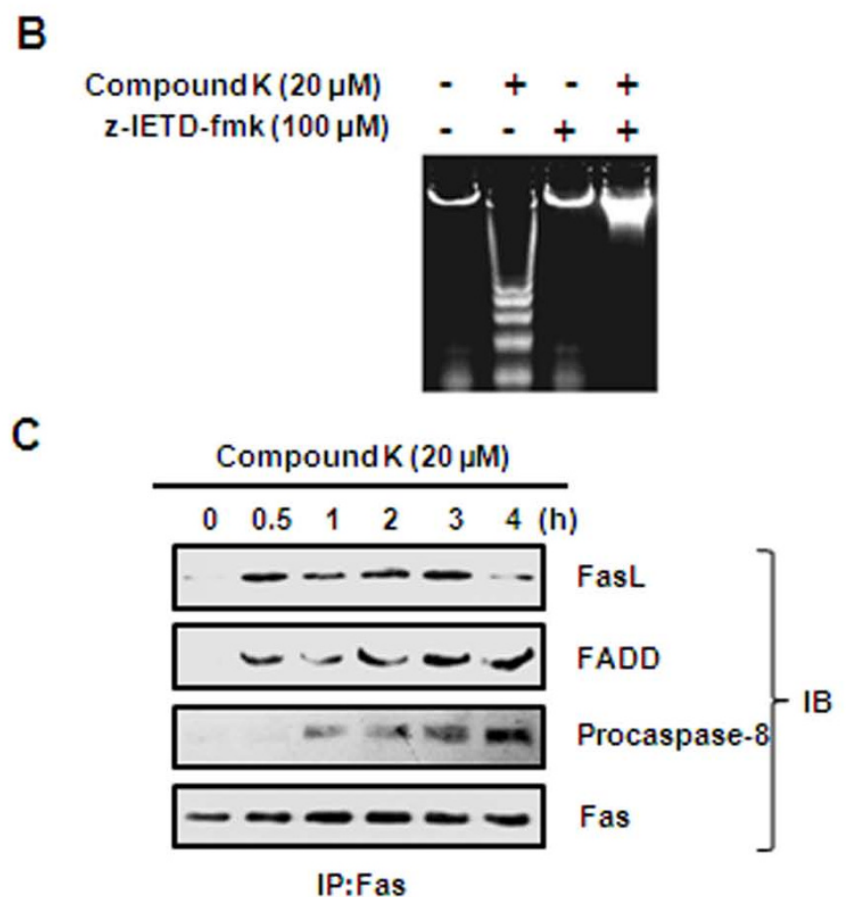

\section{Figure 5}

Effect of Compound $K$ on the requirement for caspase-8 for Compound K-induced apoptosis in $\mathrm{HL}-60$ cells. (A) HL-60 cells were pretreated with/without $100 \mu \mathrm{M}$ z-IETD-fmk (a specific caspase-8 inhibitor) for I h and then treated with 20 $\mu \mathrm{M}$ of Compound $\mathrm{K}$ for $4 \mathrm{~h}$. Mitochondrial (M) and cytosolic (C) fractions were prepared as described in Methods. Caspase-3, $\mathrm{Bid}$, and tBid were analyzed by Western blotting. Anti- $\alpha$-tubulin, anti-COX IV and anti- $\beta$-actin were used as internal controls. (B) Samples were treated as described in the legend of Figure 5(A). Genomic DNA fragments were extracted and resolved on $2 \%$ agarose gel. Apoptotic DNA fragmentation was visualized by ethidium bromide staining. (C) Fas was immunoprecipitated from total protein lysates and proteins were subjected to Western blotting for anti-FasL, anti-FADD, or anti-caspase-8 antibodies (IP: immunoprecipitation, IB; immunoblotting). 
were preincubated with cycloheximide $(1 \mu \mathrm{g} / \mathrm{mL}$ for $1 \mathrm{~h})$; a protein synthesis inhibitor and then treated with Compound $\mathrm{K}$ for $4 \mathrm{~h}$. Cycloheximide completely inhibited the activation of caspase- 8 and -3 and DNA fragmentation (Figures 6A and 6B) by Compound $\mathrm{K}$, indicating that $d e$ novo protein synthesis is required for Compound $\mathrm{K}$ induced apoptosis.

\section{Discussion}

Compound $\mathrm{K}$ is a novel ginseng saponin metabolite that is formed by the action of intestinal bacteria on ginseng extract in man and rats [3]. The intestinal bacteria Prevotella oris, which is responsible for the hydrolysis of ginsenoside Rb1 to Compound $\mathrm{K}$, has been found in $79 \%$ of human fecal specimens [21]. Since Compound K was detected in blood after oral administration of ginsenoside $\mathrm{Rb} 1$ to mice, it has been speculated that it is probably the major form of protopanaxadiol saponin absorbed by the intestine. Furthermore, evidence that Compound $\mathrm{K}$ is the active metabolite responsible for the anti-carcinogenic effects of ginseng saponins has prompted several groups to investigate its effects in detail [22-26].

Compound $\mathrm{K}$ has been reported to have potent anti-tumorigenic activity, and in particular, to inhibit 12-O-tetradecanoylphorbol-13-acetate (TPA)-induced tumor promotion in mouse skin, and COX-2 expression in mouse skin and in cultured human mammary epithelial cells [22]. In addition, Compound $\mathrm{K}$ has been reported to inhibit glucose uptake by tumor cells and to reverse multidrug resistance in bacterial and tumor cells [23]. Compound $\mathrm{K}$ was also found to have antiangiogenic activities in a spontaneous metastasis model [24,27], and to inhibit the expression of matrix metalloproteinase (MMP)-9, which regulates the growth and invasiveness of brain tumors [24]. It has also been reported to induce apoptosis in activated rat hepatic stellate [25] and hepatoma $[7,26]$ cancer cells. However, the effects of Compound $\mathrm{K}$ on leukemia have not been studied in detail, although Lee et al found that Compound $\mathrm{K}$ induced apoptosis via the cytochrome $c$-mediated activation of caspase-3 in HL-60 cells [28]. Our present results confirm those of Lee et al., in as much as Compound $\mathrm{K}$ showed cytotoxic and apoptosis-inducing activities in HL-60 cells.

Apoptosis is a fundamental cellular activity and provides protection against cancer development by eliminating genetically altered cells and hyper-proliferative cells. Thus, defects in apoptosis signaling pathways contribute to carcinogenesis and chemoresistance [29]. As mentioned above, there are two major apoptotic pathways; the extrinsic death receptor-mediated pathway and the intrinsic mitochondria-mediated pathway, and truncated Bid protein provides cross-talk between the two [30]. Both of these pathways are regulated by caspases, which are responsible, either directly or indirectly, for the cleavages of cellular proteins, a characteristic of apoptosis [31]. In the present study, Compound $\mathrm{K}$ increased the levels of cleaved caspase- $8,-9$, and -3 and PARP in a time-dependent manner and pretreatment with various caspase inhibitors markedly prevented Compound K-induced DNA fragmentation (Figure 2). These findings indicate that caspase- 3 and -8 play fundamental roles in Compound $\mathrm{K}$ induced apoptosis in HL-60 cells. It is noteworthy that the specific inhibition of caspase- 9 by z-LEHD-fmk had only a mild inhibitory effect on Compound K-stimulated apoptosis. In this regard, it appears that activation of the intrinsic mitochondria-mediated pathway alone is not sufficient to explain the apoptotic effects of Compound $\mathrm{K}$ in HL-60 leukemia cells. In addition, caspase-9 was activated about $2 \mathrm{~h}$ after treatment with Compound-K while activation of caspase- 3 was observed at $0.5 \mathrm{~h}$. Recent studies have suggested that caspase- 3 has feedback action on caspase-9 [32]. For example, caspase-3-mediated activation of caspase- 9 was involved in cisplatin-induced apoptosis [33]. This data suggested a possibility that tBid/ caspase 9 activation is a consequence of active caspase 3 in the Compound-K-induced apoptosis.

Activation of the intrinsic mitochondrial pathway leads to the release of Smac/DIABLO, which removes the IAP blockage of caspase activation [34]. The IAP family, which includes XIAP and survivin, functions by binding to and inhibiting several caspases [35]. In the present study, we observed Smac/DIABLO increased in cytoplasm and correspondingly decreased in mitochondria after treating cells with Compound $\mathrm{K}$ (data not shown), which suggests that the translocation of Smac/DIABLO from mitochondria to cytoplasm contributes to Compound K-induced apoptosis in HL-60 leukemia cells. Furthermore, Compound K-induced releases of cytochrome $c$ and Smac/DIABLO from mitochondria were seemingly associated with mitochondrial depolarization (Figure 3A). Bid, a BH3only proapoptotic member of the Bcl-2 family, undergoes proteolysis by caspase- 8 activated by cell surface death receptors, such as, Fas or TNF [36,37], and the tBid so produced, translocates to mitochondria and binds to antiapoptotic proteins, such as, Bcl-2 and Bcl-xL, which leads to a conformational change in Bax, mitochondrial depolarization, and cytochrome $c$ release from mitochondria [38]. Moreover, conformationally altered Bax stimulates the release of Smac/DIABLO from mitochondria [34], and the cytochrome $c$-releasing activity of Bid by cell surface death receptors such as Fas and TNF is antagonized by Bcl2 [37].

In the present study, Compound K-induced releases of cytochrome $c$ and Smac/DIABLO from mitochondria were seemingly associated with mitochondrial depolarization (Figure 3 ) and Compound $\mathrm{K}$ increased the translo- 
A

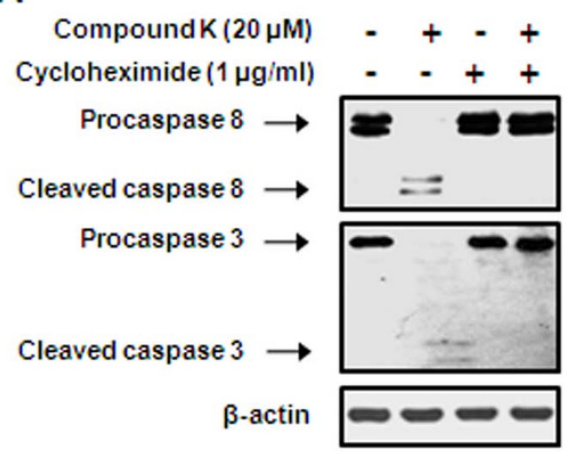

B

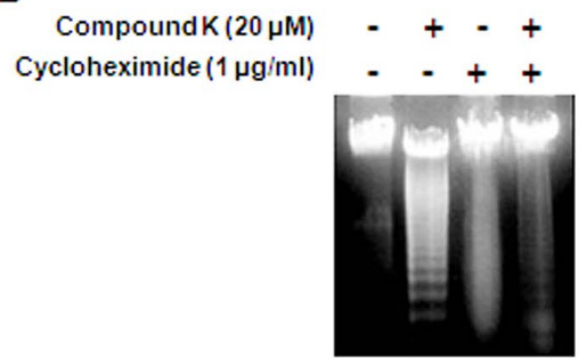

\section{Figure 6}

Effect of cycloheximide on Compound K-induced caspase activities and DNA fragmentation in HL-60

cells. (A) Cells were pretreated with I $\mu \mathrm{g} / \mathrm{mL}$ cycloheximide for $\mathrm{I} \mathrm{h}$ and then treated with $20 \mu \mathrm{M}$ of Compound $\mathrm{K}$ for $4 \mathrm{~h}$. Cleavages of procaspase- 8 and -3 were analyzed by Western blotting. (B) Compound K-induced DNA fragmentation was visualized by ethidium bromide staining.

cations of Bid and Bax to mitochondria and their bindings to $\mathrm{Bcl}-2$ and $\mathrm{Bcl}-\mathrm{xL}$, which is presumed to induce a conformational change in Bax and to reduce the mitochondrial levels of Bcl-2 and Bcl-xL in HL-60 cells (Figure 4). These findings suggest that the tBid triggered-imbalance between pro- and anti-apoptotic Bcl-2 family members is associated with the mitochondrial membrane depolarization that leads to the releases of cytochrome $c$ and Smac/ DIABLO in Compound K-treated cells.

The bindings of FasL, TRAIL, and TNF to their cell surface receptors are known to lead to caspase- 8 activation, which then amplifies the apoptotic signal either by directly activating downstream caspases or by cleaving Bid, a BH3only proapoptotic member of the Bcl-2 family [30]. In the present study, caspase- 8 inhibition prevented the cleavages of Bid and caspase- 3 and subsequent apoptosis (Figure $5 \mathrm{~A}$ ), which suggests that Bid is a substrate of caspase8 , and that caspase- 8 is required for Compound $\mathrm{K}$ induced apoptosis. Furthermore, we found that Compound $\mathrm{K}$ stimulates DISC formation with the FasL, Fas, FADD, and procaspase-8, which indicates that Com- pound K-induced caspase- 8 activation is probably due to the stimulation of the death receptors. The mechanism by which Compound K promotes DISC formation appears to be dependent on de novo protein synthesis since the Compound K-induced activation of caspases- 8 and -3 and DNA fragmentation were prevented by cycloheximide. During our earlier studies, we found FasL is abundantly expressed in HL-60 cells, and that Compound K increases Fas protein expression in a time-dependent manner, but does not affect FasL (data not shown). In this regard, we speculate that Compound $\mathrm{K}$ stimulates apoptosis by upregulating Fas in HL-60 cells. Indeed, in a previous study, the triterpene saponin platycodin $\mathrm{D}$ was demonstrated to induce DNA fragmentation and caspase-3/-8 activation within $3 \mathrm{~h}$ in immortalized keratinocyte $\mathrm{HaCa}$ cells [39]. Recent studied have demonstrated that the general translation rate is about 2-2.8 amino acid/sec suggestting that it would take only 15 min to make a 50\% change in protein concentration [40,41]. Furthermore, Fas and FasL protein upregulations were observed at 15 and 30 min, respectively, after platycodin D treatment, and NF$\kappa \mathrm{B}$ activation (mediated by the degradation of $\mathrm{I} \kappa \mathrm{B}$ ) was found to be involved in these upregulations. Other studies have also demonstrated the involvement of NF- $\kappa \mathrm{B}$ in the regulation of Fas and FasL expression in a variety of cell lines $[42,43]$. However, whether Compound K-induced apoptosis is mediated by NF- $\kappa \mathrm{B}$-regulated Fas expression in HL-60 cells remains to be determined. Taken together, we hypothesize Compound K-induced apoptosis in HL60 cells is associated with the upregulations of cleaved caspases- 8 and -3 , tBid, and mitochondrial membrane depolarization, and that crosstalk between the caspase-8/ Bid and mitochondrial pathways appears to contribute to Compound K-induced apoptosis.

\section{Conclusion}

Our results demonstrate that Compound $\mathrm{K}$ inhibit the viability of HL-60 cells and these effects were mediated through the induction of apoptosis. Compound $\mathrm{K}$ induced the activation of caspase- $3,-8$, and -9 , and modulation of Bcl- 2 families. In addition, a caspase- 8 inhibitor completely abolished caspase-3 activation, Bid cleavage, and subsequent DNA fragmentation by Compound K. Therefore caspase- 8 plays a key role in Compound K-stimulated apoptosis. Based on these finding, we suggest that Compound $\mathrm{K}$ may be used as a potential therapeutic and chemopreventive agent for leukemia via the potent apoptotic activity.

\section{Abbreviations}

Caspase: cystein arspartyl-specific protease; Smac/DIABLO: second mitochondria-derived activator of caspase/ direct inhibitor of apoptosis protein binding protein with low pI; XIAP: X-linked inhibitor of apoptosis protein; FADD: Fas-associated death domain protein. 


\section{Competing interests}

The authors declare that they have no competing interests.

\section{Authors' contributions}

SHC and KSC performed major experimental work, conceived of the study in its design and coordination, and drafted the manuscript. DHK provided the Compound $\mathrm{K}$ in collaboration. JHC and KTL participated in the overall design of study and helped to draft the manuscript. All authors read and approved the final manuscript.

\section{Acknowledgements}

This work was supported partly by a grant from the Korean Food Research Institute (2003) and partly by the Korea Science and Engineering Foundation (KOSEF) grant funded by the Korea government (MOST) (No. RI32002-020-03002-0(2007).

\section{References}

I. Attele AS, Wu JA, Yuan CS: Ginseng pharmacology: multiple constituents and multiple actions. Biochem Pharmacol 1999 58(I I): I685-1693.

2. Wakabayashi C, Murakami K, Hasegawa H, Murata J, Saiki I: An intestinal bacterial metabolite of ginseng protopanaxadiol saponins has the ability to induce apoptosis in tumor cells. Biochem Biophys Res Commun I998, 246(3):725-730.

3. Hasegawa $H$, Sung $J H$, Matsumiya $S$, Uchiyama $M$ : Main ginseng saponin metabolites formed by intestinal bacteria. Planta Med 1996, 62(5):453-457.

4. Hasegawa H, Matsumiya S, Uchiyama M, Kurokawa T, Inouye $Y$, Kasai $R$, Ishibashi S, Yamasaki K: Inhibitory effect of some triterpenoid saponins on glucose transport in tumor cells and its application to in vitro cytotoxic and antiviral activities. Planta Med 1994, 60(3):240-243.

5. Lee BH, Lee SJ, Hur JH, Lee S, Sung JH, Huh JD, Moon CK: In vitro antigenotoxic activity of novel ginseng saponin metabolites formed by intestinal bacteria. Planta Med 1998, 64(6):500-503.

6. Choo MK, Sakurai H, Kim DH, Saiki I: A ginseng saponin metabolite suppresses tumor necrosis factor-alpha-promoted metastasis by suppressing nuclear factor-kappaB signaling in murine colon cancer cells. Oncol Rep 2008, I 9(3):595-600.

7. $\mathrm{Oh} \mathrm{SH}$, Lee $\mathrm{BH}$ : A ginseng saponin metabolite-induced apoptosis in HepG2 cells involves a mitochondria-mediated pathway and its downstream caspase-8 activation and Bid cleavage. Toxicol Appl Pharmacol 2004, I 94(3):221-229.

8. Choi HH, Jong HS, Park JH, Choi S, Lee JW, Kim TY, Otsuki T, Namba $M$, Bang Y]: A novel ginseng saponin metabolite induces apoptosis and down-regulates fibroblast growth factor receptor 3 in myeloma cells. Int J Oncol 2003, 23(4): I087-I093.

9. Kim YS, Jin SH, Lee YH, Kim SI, Park JD: Ginsenoside Rh2 induces apoptosis independently of $\mathrm{Bcl}-2, \mathrm{Bcl}-\mathrm{xL}$, or $\mathrm{Bax}$ in C6Bu-I cells. Arch Pharm Res 1999, 22(5):448-453.

10. Ahmad N, Feyes DK, Nieminen AL, Agarwal R, Mukhtar H: Green tea constituent epigallocatechin-3-gallate and induction of apoptosis and cell cycle arrest in human carcinoma cells. J Natl Cancer Inst 1997, 89(24): | 881-1886

II. Kruidering M, Evan GI: Caspase-8 in apoptosis: the beginning of "the end"? IUBMB Life 2000, 50(2):85-90.

12. Stennicke HR, Jurgensmeier JM, Shin H, Deveraux $Q$, Wolf BB, Yang $X$, Zhou Q, Ellerby HM, Ellerby LM, Bredesen D, et al.: Pro-caspase3 is a major physiologic target of caspase-8. J Biol Chem 1998, 273(42):27084-27090.

13. Kaufmann SH, Earnshaw WC: Induction of apoptosis by cancer chemotherapy. Exp Cell Res 2000, 256(I):42-49.

14. Yuan J, Lipinski M, Degterev A: Diversity in the mechanisms of neuronal cell death. Neuron 2003, 40(2):40I-4I3.

15. Susin SA, Lorenzo HK, Zamzami N, Marzo I, Snow BE, Brothers GM, Mangion J, Jacotot E, Costantini P, Loeffler M, et al.: Molecular characterization of mitochondrial apoptosis-inducing factor. Nature 1999, 397(67 I 8):44|-446.
16. Li LY, Luo X, Wang X: Endonuclease $\mathbf{G}$ is an apoptotic DNase when released from mitochondria. Nature 200I, 4I 2(6842):95-99.

17. Choo MK, Park EK, Han MJ, Kim DH: Antiallergic activity of ginseng and its ginsenosides. Planta Med 2003, 69(6):5 I 8-522.

18. Mosmann T: Rapid colorimetric assay for cellular growth and survival: application to proliferation and cytotoxicity assays. J Immunol Methods 1983, 65(1-2):55-63.

19. Lee KW, Kim HJ, Lee YS, Park HJ, Choi JW, Ha J, Lee KT: Acteoside inhibits human promyelocytic HL-60 leukemia cell proliferation via inducing cell cycle arrest at G0/G I phase and differentiation into monocyte. Carcinogenesis 2007, 28(9): 1928-1936.

20. Dewson G, Snowden RT, Almond JB, Dyer MJ, Cohen GM: Conformational change and mitochondrial translocation of Bax accompany proteasome inhibitor-induced apoptosis of chronic lymphocytic leukemic cells. Oncogene 2003, 22( I 7):2643-2654.

2I. Hasegawa $H$, Sung $J \mathrm{H}$, Huh $\mathrm{H}$ : Ginseng intestinal bacterial metabolite IH90 I as a new anti-metastatic agent. Arch Pharm Res 1997, 20(6):539-544.

22. Surh YJ, Lee JY, Choi KJ, Ko SR: Effects of selected ginsenosides on phorbol ester-induced expression of cyclooxygenase-2 and activation of NF-kappaB and ERKI/2 in mouse skin. Ann N Y Acad Sci 2002, 973:396-40I.

23. Hasegawa H, Sung JH, Matsumiya S, Uchiyama M, Inouye Y, Kasai R, Yamasaki K: Reversal of daunomycin and vinblastine resistance in multidrug-resistant $\mathbf{P} 388$ leukemia in vitro through enhanced cytotoxicity by triterpenoids. Planta Med 1995, 6I(5):409-4I3

24. Jung SH, Woo MS, Kim SY, Kim WK, Hyun JW, Kim EJ, Kim DH, Kim HS: Ginseng saponin metabolite suppresses phorbol esterinduced matrix metalloproteinase-9 expression through inhibition of activator protein-I and mitogen-activated protein kinase signaling pathways in human astroglioma cells. Int J Cancer 2006, I I 8(2):490-497.

25. Park EJ, Zhao YZ, Kim J, Sohn DH: A ginsenoside metabolite, 20O-beta-D-glucopyranosyl-20(S)-protopanaxadiol, triggers apoptosis in activated rat hepatic stellate cells via caspase-3 activation. Planta Med 2006, 72(I3): | 250-I253.

26. Ming YL, Song G, Chen LH, Zheng ZZ, Chen ZY, Ouyang GL, Tong $\mathrm{QX}$ : Anti-proliferation and apoptosis induced by a novel intestinal metabolite of ginseng saponin in human hepatocellular carcinoma cells. Cell Biol Int 2007, 3 I ( I 0): | 265- I 273.

27. Hasegawa $\mathrm{H}$, Sung JH, Benno Y: Role of human intestinal Prevotella oris in hydrolyzing ginseng saponins. Planta Med 1997, 63(5):436-440.

28. Lee SJ, Ko WG, Kim JH, Sung JH, Moon CK, Lee BH: Induction of apoptosis by a novel intestinal metabolite of ginseng saponin via cytochrome c-mediated activation of caspase-3 protease. Biochem Pharmacol 2000, 60(5):677-685.

29. Hickman JA: Apoptosis induced by anticancer drugs. Cancer Metastasis Rev 1992, I I(2): I 2 | - I 39.

30. Hengartner MO: The biochemistry of apoptosis. Nature 2000 407(6805):770-776.

31. Grutter MG: Caspases: key players in programmed cell death. Curr Opin Struct Biol 2000, I 0(6):649-655.

32. Fujita E, Egashira J, Urase K, Kuida K, Momoi T: Caspase-9 processing by caspase-3 via a feedback amplification loop in vivo. Cell Death Differ 200I, 8(4):335-344.

33. Blanc C, Deveraux QL, Krajewski S, Janicke RU, Porter AG, Reed JC, Jaggi $R$, Marti A: Caspase-3 is essential for procaspase-9 processing and cisplatin-induced apoptosis of MCF-7 breast cancer cells. Cancer Res 2000, 60( I 6):4386-4390.

34. Deng $Y$, Lin $Y, W u ~ X:$ TRAIL-induced apoptosis requires Baxdependent mitochondrial release of Smac/DIABLO. Genes Dev 2002, I 6(I):33-45

35. Deveraux OL, Roy N, Stennicke HR, Van Arsdale T, Zhou Q, Srinivasula SM, Alnemri ES, Salvesen GS, Reed JC: IAPs block apoptotic events induced by caspase- 8 and cytochrome $c$ by direct inhibition of distinct caspases. EMBO J | 998, I 7(8):22 I5-2223.

36. Li H, Zhu H, Xu CJ, Yuan J: Cleavage of BID by caspase 8 mediates the mitochondrial damage in the Fas pathway of apoptosis. Cell I998, 94(4):49I-50I.

37. Luo X, Budihardjo I, Zou H, Slaughter C, Wang X: Bid, a Bcl2 interacting protein, mediates cytochrome $c$ release from mito- 
chondria in response to activation of cell surface death receptors. Cell 1998, 94(4):48I-490.

38. Desagher S, Osen-Sand A, Nichols A, Eskes R, Montessuit S, Lauper $\mathrm{S}$, Maundrell K, Antonsson B, Martinou JC: Bid-induced conformational change of Bax is responsible for mitochondrial cytochrome c release during apoptosis. J Cell Biol 1999, | 44(5):89|-90|.

39. Ahn KS, Hahn BS, Kwack K, Lee EB, Kim YS: Platycodin D-induced apoptosis through nuclear factor-kappaB activation in immortalized keratinocytes. Eur J Pharmacol 2006, 537(I3): I-II.

40. Zouridis $\mathrm{H}$, Hatzimanikatis $\mathrm{V}$ : A model for protein translation: polysome self-organization leads to maximum protein synthesis rates. Biophys / 2007, 92(3):717-730.

4I. Wu JQ, Pollard TD: Counting cytokinesis proteins globally and locally in fission yeast. Science 2005, 31 0(5746):3 I 0-3 I 4 .

42. Fujita M, Goto $K$, Yoshida $K$, Okamura $H$, Morimoto $H$, Kito $S$, Fukuda J, Haneji T: Okadaic acid stimulates expression of Fas receptor and Fas ligand by activation of nuclear factor kappa-B in human oral squamous carcinoma cells. Oral Oncol 2004, 40(2):199-206.

43. Kasibhatla S, Brunner T, Genestier L, Echeverri F, Mahboubi A, Green DR: DNA damaging agents induce expression of Fas ligand and subsequent apoptosis in $\mathrm{T}$ lymphocytes via the activation of NF-kappa B and AP-I. Mol Cell 1998, I (4):543-55I.

\section{Pre-publication history}

The pre-publication history for this paper can be accessed here:

http://www.biomedcentral.com/1471-2407/9/449/prepub 